\title{
A comparative study to evaluate the effect of limited access dressing on diabetic ulcers
}

\section{Thittamaranahalli Muguregowda Honnegowda ${ }^{1}$, Pramod Kumar ${ }^{1,2}$, Krishnananda Prabhu ${ }^{3}$, Ashwini Kumar ${ }^{4}$, Pragna Rao ${ }^{3}$, E. G. Padmanabha Udupa ${ }^{3}$, Shobha Kamath ${ }^{3}$, Antony Sylvan D' Souza ${ }^{5}$, Krishna Kishore Mahato ${ }^{6}$}

${ }^{1}$ Department of Plastic Surgery and Burns, Kasturba Medical College, Manipal 576104, Karnataka, India.

${ }^{2}$ Department of Plastic Surgery, King Abdulaziz Specialist Hospital, Sakaka 42421, Al-Jouf, Saudi Arabia.

${ }^{3}$ Department of Biochemistry, Kasturba Medical College, Manipal 576104, Karnataka, India.

${ }^{4}$ Department of Forensic Medicine, Kasturba Medical College, Manipal 576104, Karnataka, India.

${ }^{5}$ Department of Anatomy, Kasturba Medical College, Manipal 576104, Karnataka, India.

${ }^{6}$ Department of Biophysics, School of Life Sciences, Manipal 576104, Karnataka, India.

Address for correspondence: Dr. Thittamaranahalli Muguregowda Honnegowda, Department of Plastic Surgery and Burns, Kasturba Medical College, Manipal 576104, Karnataka, India. E-mail: honnegowda33@gmail.com

\begin{abstract}
Aim:Emerging evidence favors theimportant role of antioxidants, matrix metalloproteinases(MMPs), and nitric oxide (NO) in the healing of diabetic wounds. There is a lack of substantial evidence regarding the effects of negative pressure on antioxidants, MMPs and NO in chronic wounds associated with diabetes. Methods: A total of 55 type 2 diabetic patients with leg ulcers were divided into 2 groups: a limited access dressing (LAD) group $(n=27)$ and a conventional dressing group $(n=28)$. Levels of hydroxyproline, total protein, MMP-2 and MMP-9, NO and antioxidants including reduced glutathione (GSH) and the oxidative biomarker malondialdehyde (MDA) were measured in the granulation tissue at days 0 and 10. Changes in levels between the LAD and conventional groups were determined by the Student's t-test. Results: After 10 days of treatment, the LAD vs. conventional dressing group showed increase in the levels of hydroxyproline (mean \pm standard deviation $=55.2 \pm 25.1$ vs. $29.2 \pm 1, P<0.05$ ), total protein (12.8 \pm 6.5 vs. $8.34 \pm 3.2, P<0.05)$, NO (1.13 \pm 0.52 vs. $0.66 \pm 0.43, P<0.05), \mathrm{GSH}(7.0 \pm 2.4$ vs. $6.6 \pm 2.2, P<0.05)$ and decrease in MMP-2 (0.47 \pm 0.33 vs. $0.62 \pm 0.30, P<0.05)$, MMP-9 $(0.32 \pm 0.20$ vs. $0.53 \pm 0.39, P<0.05)$ and MDA $(6.8 \pm 2.3$ vs. $10.4 \pm 3.4, P<0.05)$. Conclusion: When compared to conventional dressings, LAD induces biochemical changes by significantly increasing the levels of hydroxyproline, total protein, NO and antioxidants levels, and significantly reducing MMPs (MMP-2 and MMP-9) and an oxidative biomarker in diabetic wounds. These biochemical changes are thought to favor diabetic wound healing.
\end{abstract}

Key words:

Antioxidants, diabetic wounds, hydroxyproline, limited access dressing, matrix metalloproteinases, nitric oxide, reactive oxygen species and oxidative stress biomarker, total protein

\begin{tabular}{|l|l|}
\hline \multicolumn{2}{|c|}{ Access this article online } \\
\hline Quick Response Code: & Website: \\
\cline { 1 - 2 } & www.parjournal.net \\
\cline { 1 - 2 } & \\
\hline & \\
\hline
\end{tabular}

This is an open access article distributed under the terms of the Creative Commons Attribution-NonCommercial-ShareAlike 3.0 License, which allows others to remix, tweak, and build upon the work non-commercially, as long as the author is credited and the new creations are licensed under the identical terms.

For reprints contact: reprints@medknow.com

How to cite this article: Honnegowda TM, Kumar P, Prabhu K, Kumar A, Rao P, Padmanabha Udupa EG, Kamath S, D' Souza AS, Mahato KK. A comparative study to evaluate the effect of limited access dressing on diabetic ulcers. Plast Aesthet Res 2015;2:266-71.

Received: 02-05-2015; Accepted: 28-06-2015 


\section{INTRODUCTION}

Wound healing is a self-regulated physiological process of cell regeneration which occurs without any external stimuli. This is accomplished by the stages of fibroplasia, angiogenesis, and migration of fibroblasts, endothelial, and epithelial cells, finally leading to the wound contraction. ${ }^{[1]}$ Inflammation is a vital and protective response instigated by injured cells at the wound site which begins the process of tissue repair. ${ }^{[2]}$ In response to inflammation, reactive oxygen species (ROS) such as free radicals (superoxide anion radical: $\mathrm{O}_{2}^{-}$) and nonradical hydrogen peroxide $\left(\mathrm{H}_{2} \mathrm{O}_{2}\right)$, are generated continuously until inflammation subsidies. ${ }^{[3]}$ Free radicals and their scavenging systems play an important role in normal and delayed wound healing. ${ }^{\mid 4,5]}$

Delayed healing of diabetic wounds is characterized by an increase in matrix metalloproteinases (MMPs), a decrease in the tissue inhibitors of metalloproteinases (TIMPs), ${ }^{[6]}$ and an altered magnitude of free radical generation and disposal. ${ }^{[7]}$ An imbalance between oxidant and antioxidant defense mechanisms leads to oxidative stress resulting in lipid peroxidation, DNA damage, and inactivation of free radical scavenger enzymes. ${ }^{[8]}$ This leads to tissue damage and impairs the healing process in diabetic wounds with reduced angiogenesis, altered proliferation of fibroblasts, reduced fibroblast migration, inadequate collagen deposition, advanced glycation, and abnormal mitochondrial function. ${ }^{[9-11]}$

Nitric oxide (NO) is a mediator which plays an important role in wound healing and has been implicated in diabetic wounds. Reduced levels can cause alterations in vascular permeability and a reduction of capillary flow causing oxidative stress. ${ }^{[12]}$ Antioxidants such as reduced glutathione (GSH), glutathione peroxidase (GPx), catalase (CAT), and thiol (-SH) prevent the generation and action of ROS. Hence, antioxidants that provide potential mechanisms for wound healing can ameliorate diabetic complications by both significantly preventing tissue damage and stimulating the wound healing process. ${ }^{[13,14]}$

Several studies have demonstrated the negative role of free radicals on wound healing; reduction of persistent inflammation; and elimination of free radicals may improve healing in diabetic wounds. ${ }^{[15]}$ Although advanced technologies have been developed for the treatment of diabetic wounds, outcomes have been poor. Negative pressure wound therapy (NPWT) has emerged as a treatment for complex wounds. This is a noninvasive system which creates a localized and controlled sub atmospheric pressure environment. Wound healing by delayed primary or secondary intention is promoted by the creation of a moist wound environment which prepares the wound bed for closure, reduces edema, and promotes the formation and perfusion of granulation tissue. ${ }^{116,17]}$ The clinical evidence supporting the use of continuous NPWT on diabetic wounds has been based largely on clinician perception, case series, small cohort studies, and weakly powered randomized trials that constitute a substantial number of publications but an overall low amount of evidence. Evidence is lacking on the use of an intermittent negative pressure dressing which would be more economical and clinically acceptable ${ }^{[17]}$ than the use of continuous NPWT.

The present study evaluates the role of intermittent negative pressure using limited access dressing (LAD) (a cycle of 30 min of suction and $3.5 \mathrm{~h}$ of rest) on diabetic wounds by measuring and comparing the levels of hydroxyproline, total protein, NO, antioxidants (GSH), and an oxidative biomarker malondialdehyde (MDA) in the granulation tissue of type 2 diabetes mellitus ulcer patients.

\section{METHODS}

\section{Ethical approval and informed consent}

This prospective randomized controlled trial study was carried out in the Department of Plastic Surgery, Kasturba Hospital, Manipal. The Institutional Ethics Committee reviewed and approved the study protocol. Written informed consent was obtained from all patients or their next of kin prior to inclusion in the study.

\section{Study design}

Patients were diagnosed on the basis of history, physical examination, and biochemical investigation. Seventy-five patients more than 40 years of age (mean age: 56 years) suffering from chronic diabetic wounds with insulin-controlled diabetes were enrolled in the study. After evaluation for inclusion (diabetic leg ulcers) and exclusion criteria (collagen disorders, leprosy, pregnancy, cirrhosis, and HIV positive status), 55 patients were randomized of whom 27 were assigned to the LAD group and 28 were assigned to the conventional dressing group. Biopsies were taken from both groups on day 0 of the study. The LAD group patients were treated with intermittent negative pressure and a moist wound environment, and wounds were washed daily with a solution of povidone-iodine. Conventional dressing group patients were dressed daily with $5 \%$ povidone-iodine solution soaked gauze. On day 10 , granulation tissue biopsies were taken from both groups and subjected to biochemical study by an investigator blinded to the clinical data.

\section{Randomization}

Patients were randomized by generating tables of random numbers through www.random.org. Numbers were assigned to a treatment group and sealed in opaque envelopes containing labeled paper with the treatment and the patient's ID.

\section{Chemicals}

All chemical used were of analytical grade. Standard L-hydroxyproline, bovine serum albumin (BSA), standard GSH, 1-chloro-2,4-dinitrobenzene, and cumene $\mathrm{H}_{2} \mathrm{O}_{2}$ were purchased from Sigma-Aldrich (St. Louis, MO, USA). Thiobarbituric acid (TBA), trichloroacetic acid (TCA), 1,1,3,3-tetramethoxypropane N-ethylmaleimide (NEM), and orthophosphoric acid were purchased from S.D. Fine-Chemicals Ltd. (Boisar, India). 


\section{Tissue preparation for assays}

\section{Tissue preparation for hydroxyproline estimation}

The granulation tissue specimens were dried at $60^{\circ} \mathrm{C}$ for $24 \mathrm{~h}$ and then were weighed and kept in glass-stoppered test tubes. $6 \mathrm{~N} \mathrm{HCl}$ was added to each tube for a total of $40 \mathrm{mg}$ of dried granulation tissue per $\mathrm{ml}$ of acid. The tubes were kept in boiling water bath for a total of $24 \mathrm{~h} \mathrm{(12} \mathrm{h}$ and each for 2 days) for hydrolysis. The hydrolysate was then cooled, and the excess acid was neutralized by $10 \mathrm{~N}$ sodium hydroxide $(\mathrm{NaOH})$ using phenolphthalein/methyl red as an indicator. The volume of neutral hydrolysate was diluted with distilled water to a concentration of $20 \mathrm{mg} / \mathrm{mL}$ of dried granulation tissue in the final hydrolysate. The hydrolysate was used to estimate the level of hydroxyproline. ${ }^{[18]}$

Tissue preparation for estimation of antioxidants and oxidative biomarkers

The wet weight of the granulation tissue samples was noted and homogenized by a Rotex homogenizer in ice-cold $0.2 \mathrm{M}$ phosphate buffer ( $\mathrm{pH}$ 7.4). Homogenates were centrifuged at $15,000 \mathrm{rpm}$ for $30 \mathrm{~min}$ in a cooling centrifuge, and the supernatant was then used to determine total protein, GSH, and an oxidative biomarker (MDA).

For the MMP-2 assay, the granulation tissue was rinsed in ice-old phosphate buffer saline (PBS) $(0.1 \mathrm{~mol} / \mathrm{L}$, $\mathrm{pH}$ 7.0-7.2) to remove all traces of excess blood and weighed prior to homogenization. The tissues were minced into small pieces and homogenized on ice in $5 \mathrm{~mL}$ of PBS. The resulting suspension was sonicated with an ultrasonic cell disrupter or subjected to two freeze-thaw cycles to further break the cell membranes. The homogenates were then centrifuged for $5 \mathrm{~min}$ at $50 \mathrm{~g}$, removing the supernatant and aliquot store at no more than $-80^{\circ} \mathrm{C}$.

For the NO assay, the tissue was homogenized in an isotonic solution of PBS containing $10 \mathrm{mM}$ of NEM and $2.5 \mathrm{mmol}$ ethylenediaminetetraacetic acid (EDTA). The addition of NEM/EDTA blocks the SH-groups while inhibiting the transition of metal-catalyzed trans-nitrosation reactions, preventing artificial nitrosation and thiolate- and ascorbate-mediated degradation of endogenous Nitrosothiols and nitrite $\left(\mathrm{NO}_{2}^{-}\right)$. The protein concentration was determined according to Lowry et al. ${ }^{[19]}$ using purified BSA as the standard.

\section{Estimation of biochemical parameters \\ Hydroxyproline}

The dried tissue was added to $10 \mathrm{~mL}$ of $6 \mathrm{~N} \mathrm{HCl}$ and stored at $110^{\circ} \mathrm{C}$ for $24 \mathrm{~h}$. The neutralized acid hydrolysate of the dry tissue was used to determine the level of hydroxyproline. The reaction mixture contains $0.05 \mathrm{M}$ copper sulfate, $2.5 \mathrm{~N} \mathrm{NaOH}, 6 \% \mathrm{H}_{2} \mathrm{O}_{2}$, $3 \mathrm{~N}$ sulfuric acid, and 5\% p-dimethylaminobenzaldehyde using L-hydroxyproline as the standard. Absorbance was measured at $540 \mathrm{~nm}$ and expressed as $\mu \mathrm{g} / \mathrm{mg}$ of dry tissue weight. ${ }^{[18]}$

\section{Total protein}

The total protein content of the wound tissue homogenate was determined according to the method of Lowry et al. ${ }^{[19]}$ Absorbance was measured at $540 \mathrm{~nm}$ and expressed in $\mathrm{mg} / \mathrm{g}$ of tissue. Standards were treated similarly using BSA at concentrations of $0,20,40,60,80$, and $100 \mu \mathrm{g} / \mathrm{mL}$ in $0.1 \mathrm{M}$ phosphate buffer at $\mathrm{pH}$ 7.4.

\section{Matrix metalloproteinase-2 and -9}

A total of $100 \mathrm{mg}$ of tissue was homogenized in $1 \mathrm{~mL}$ of ice-cold lysis buffer. Subsequently, homogenates were centrifuged at $3,000 \mathrm{~g}$ for $5 \mathrm{~min}$ at $4^{\circ} \mathrm{C}$, and supernatants were stored at $-80^{\circ} \mathrm{C}$ until use. MMP-2 and MMP-9 were measured using prefabricated ELISA kits, according to manufacturer protocol ( $R$ and D Systems, USCN Life Science Inc., USA). Plates were read at $450 \mathrm{~nm}$ and $540 \mathrm{~nm}$, and concentrations were calculated using a 4-point standard curve and expressed as $\mathrm{ng} / \mathrm{mg}$ of protein. ${ }^{|20|}$

\section{Nitric oxide estimation}

The level of $\mathrm{NO}$ was estimated as $\mathrm{NO}_{2}{ }^{-}$, an $\mathrm{NO}$ metabolite in tissue samples. NO is a highly reactive free radical gas which is a ready oxidizer and remains stored in tissues as nitrates $\left(\mathrm{NO}_{3}^{-}\right)$or $\mathrm{NO}_{2}^{-}$. Thus, $\mathrm{NO}$ concentration can be estimated by measuring concentrations of $\mathrm{NO}_{3}{ }^{-}$and $\mathrm{NO}_{2}{ }^{-}$ in combination. The simplest technique is to monitor the reduction of $\mathrm{NO}_{3}{ }^{-}$to $\mathrm{NO}_{2}{ }^{-}$by nitrate reductase or a metallic catalyst, followed by the colorimetric Griess reaction to measure $\mathrm{NO}_{2}{ }^{-}$levels (nitrite levels).

Sample $\mathrm{NO}_{2}{ }^{-}$levels were estimated by a colorimetric assay which is based on the Griess reaction. Using a two-step diazotization reaction, acidified $\mathrm{NO}_{2}^{-}$produces a nitrosating agent which reacts with sulfa nitric acid to produce the diazonium ion. This ion is then coupled to $\mathrm{N}$-(1-naphthyl) ethylenediamine dihydrochloride to form a red azo derivative which is measured at $550 \mathrm{~nm}$ using a spectrophotometer. The concentrations of $\mathrm{NO}_{2}^{-}$are calculated from a standard curve established with serial dilutions of sodium $\mathrm{NO}_{2}{ }^{-} \cdot{ }^{\mid 21]}$

\section{Glutathione estimation}

The reaction mixture was prepared by adding $80 \mu \mathrm{L}$ of tissue supernatant to $0.9 \mathrm{~mL}$ of $0.2 \mathrm{M}$ sodium phosphate buffer of $\mathrm{pH} 7.00$ and $20 \mu \mathrm{L}$ of $10 \mathrm{mM} 5.5$-dithiobis (2-nitrobenzoic acid) (DTNB) solution. The yellow-colored substance formed by the reaction of GSH and DTNB was measured at $412 \mathrm{~nm}$. The results were expressed as GSH $\mu \mathrm{mol} / \mathrm{mg}$ protein. ${ }^{\mid 22]}$

\section{Malondialdehyde}

The MDA levels of wound tissue homogenate were measured according to the method of Ohkawa et al. ${ }^{[23]}$ To $0.1 \mathrm{~mL}$ of the test sample, $1 \mathrm{~mL}$ of $10 \%$ TCA and $1 \mathrm{~mL}$ of $0.67 \%$ TBA were added and then heated in a boiling water bath at $100^{\circ} \mathrm{C}$ for $30 \mathrm{~min}$. The mixture was cooled under tap water and centrifuged at 12,000 rpm for $10 \mathrm{~min}$. Clear supernatant was determined by the absorbance at $535 \mathrm{~nm}$ and expressed as nmol/mg protein.

\section{Statistical analysis}

Statistical analysis for biochemical parameters was performed by Student's $t$-test, and data were expressed as 
mean \pm standard deviation (SD). $P<0.05$ was considered to be significant, when appropriate, statistical uncertainty was expressed by $95 \%$ confidence levels.

\section{RESULTS}

A total of 75 patients were enrolled of which 55 patients were randomized; with 27 patients assigned to the LAD group and 28 patients assigned to the conventional group [Figure 1]. Five participants were lost to follow-up (two in the LAD and three in the conventional group) before the biopsies could be taken. The results of hydroxyproline, total protein, MMP-2 and MMP-9, GSH, NO, and MDA levels in diabetic ulcers are shown [Table 1].

\section{Hydroxyproline}

After 10 days of treatment, the LAD group had significantly higher hydroxyproline level (mean $\pm \mathrm{SD}=$ $55.2 \pm 25.1 \mu \mathrm{g} / \mathrm{mg}$ dry tissue weight) than the conventional group (29.2 $\pm 13.5 \mu \mathrm{g} / \mathrm{mg}$ dry tissue weight), $P=0.000$.

\section{Total protein}

After 10 days of treatment, the LAD group had significantly higher total protein levels (mean $\pm \mathrm{SD}=12.8 \pm 6.5 \mathrm{mg} / \mathrm{g}$ wet tissue weight) than

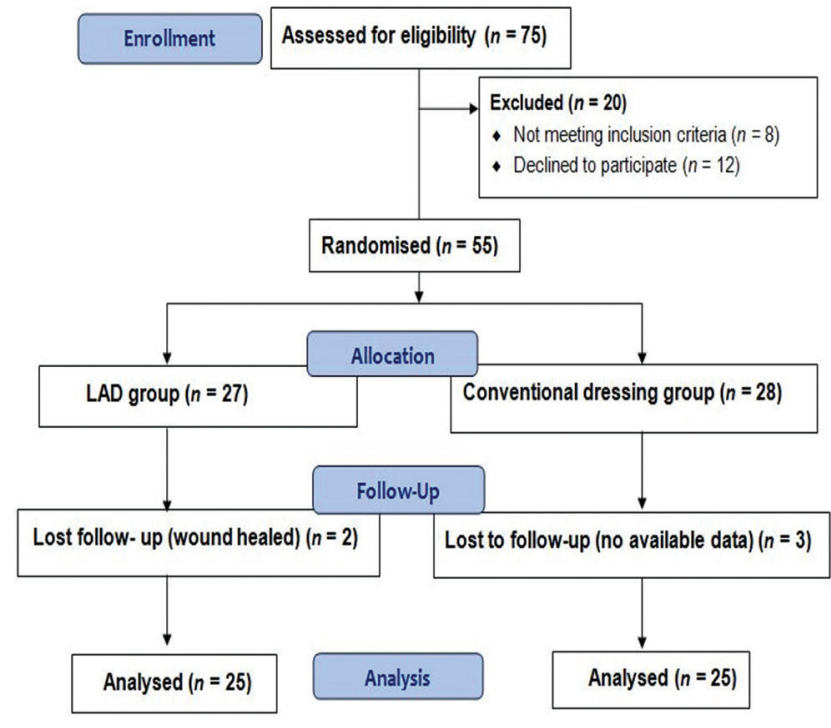

Figure 1: Consort flow chart the conventional group $(8.34 \pm 3.2 \mathrm{mg} / \mathrm{g}$ wet tissue weight), $P=0.011$.

\section{Matrix metalloproteinases-2 and matrix metalloproteinases-9}

After 10 days of treatment, MMP-2 (0.47 $\pm 0.33 \mathrm{ng} / \mathrm{mg}$ tissue protein, $P=0.041)$ and MMP-9 levels $(0.32 \pm 0.20 \mathrm{ng} / \mathrm{mg}$ tissue protein, $P=0.037$ ) in LAD group were significantly lower than the conventional group MMP-2 $(0.62 \pm 0.30 \mathrm{ng} / \mathrm{mg}$ tissue protein) and MMP-9 $(0.53 \pm 0.39 \mathrm{ng} / \mathrm{mg}$ tissue protein).

\section{Nitric oxide}

After 10 days of treatment, the LAD group had a significantly high total protein level (mean $\pm \mathrm{SD}=$ $1.13 \pm 0.52 \mathrm{nmol} / \mathrm{mg}$ protein) than the conventional group $(0.66 \pm 0.43 \mathrm{nmol} / \mathrm{mg}$ protein), $P=0.019$.

\section{Reduced glutathione}

After 10 days of treatment, antioxidant (reduced GSH) levels in the LAD group were significantly higher (mean $\pm \mathrm{SD}=7.0 \pm 2.4 \mu \mathrm{mol} / \mathrm{mg}$ protein) as compared to those in the conventional dressing group $(6.6 \pm 2.2 \mu \mathrm{mol} / \mathrm{mg}$ protein), $P=0.044$.

\section{Malondialdehyde}

After 10 days of treatment, MDA levels were significantly higher in the conventional dressing group (mean $\pm \mathrm{SD}=10.4 \pm 3.4 \mathrm{nmol} / \mathrm{mg}$ protein) as compared to the LAD group $(6.8 \pm 2.3 \mathrm{nmol} / \mathrm{mg}$ protein $), P=0.024$.

\section{DISCUSSION}

Diabetes is a multisystem disorder which induces physiological changes in tissues and cells that impair the normal healing process. Diabetic wounds can have prolonged periods in the inflammatory phase of healing, with a continuous influx of neutrophils that release cytotoxic enzymes, free radicals, and inflammatory mediators, causing extensive collateral damage to the surrounding tissue. ${ }^{[24-26]}$

In the treatment of diabetic ulcers, the NPWT wound dressing provides faster wound resolution as compared to gauze dressings. NPWT may be beneficial in the treatment of nonhealing diabetic wounds of the lower

Table 1: Results of hydroxyproline, total protein, MMP-2 and MMP-9, NO, GSH, and MDA levels in granulation tissue of diabetic ulcer in LAD group and conventional dressing group

\begin{tabular}{|c|c|c|c|c|c|c|c|}
\hline \multirow[t]{3}{*}{ Parameters } & \multicolumn{6}{|c|}{ Mean \pm SD } & \multirow[t]{3}{*}{$P$} \\
\hline & \multicolumn{3}{|c|}{ LAD group } & \multicolumn{3}{|c|}{ Conventional dressing group } & \\
\hline & Day 0 & Day 10 & Day $(0-10)$ & Day 0 & Day 10 & Day $(0-10)$ & \\
\hline Hydroxyproline ( $\mu \mathrm{g} / \mathrm{mg}$ of dry weight of tissue) & $46.9 \pm 16.0$ & $100 \pm 6.6$ & $55.2 \pm 25.1$ & $51.5 \pm 10.9$ & $80.7 \pm 15.6$ & $29.2 \pm 13.5$ & 0.000 \\
\hline Total protein (mg/g of wet weight tissue) & $11.7 \pm 3.2$ & $24.3 \pm 5.9$ & $12.8 \pm 6.5$ & $12.0 \pm 2.6$ & $20.6 \pm 4.8$ & $8.34 \pm 3.2$ & 0.011 \\
\hline MMP-2 (ng/mg tissue protein) & $0.95 \pm 0.20$ & $0.48 \pm 0.42$ & $0.47 \pm 0.33$ & $0.97 \pm 0.52$ & $0.35 \pm 0.49$ & $0.62 \pm 0.30$ & 0.041 \\
\hline MMP-9 (ng/mg tissue protein) & $0.87 \pm 0.54$ & $0.55 \pm 0.25$ & $0.32 \pm 0.20$ & $0.93 \pm 0.22$ & $0.40 \pm 0.32$ & $0.53 \pm 0.39$ & 0.037 \\
\hline $\mathrm{NO}(\mathrm{nmol} / \mathrm{mg}$ protein) & $2.0 \pm 1.42$ & $3.13 \pm 1.3$ & $1.13 \pm 0.52$ & $2.74 \pm 1.4$ & $3.4 \pm 1.44$ & $0.66 \pm 0.43$ & 0.019 \\
\hline $\mathrm{GSH}(\mu \mathrm{mol} / \mathrm{mg}$ protein $)$ & $16.1 \pm 4.3$ & $23.1 \pm 3.3$ & $7.0 \pm 2.4$ & $14.9 \pm 3.5$ & $21.5 \pm 3.79$ & $6.6 \pm 2.2$ & 0.044 \\
\hline MDA (nmol/mg protein) & $19.3 \pm 3.8$ & $12.5 \pm 4.8$ & $6.8 \pm 2.3$ & $19.9 \pm 4.5$ & $9.5 \pm 4.5$ & $10.4 \pm 3.4$ & 0.024 \\
\hline
\end{tabular}

MMP: Matrix metalloproteinase, NO: Nitric oxide, GSH: Glutathione, MDA: Malondialdehyde, LAD: Limited access dressing, SD: Standard deviation 
extremity. ${ }^{[27]}$ The intermittent negative pressure regimen used in LAD has been shown to be an economical and effective alternative in treating traumatic wounds. ${ }^{[28,29]}$

Evidence shows that increased oxidative stress causes delayed wound healing in diabetics with altered antioxidant enzyme activities. ${ }^{[30]}$ Various studies ${ }^{[31,32]}$ have shown a significant reduction in collagen content in the granulation tissue of diabetic animals. The authors of these studies have proposed that the decreased collagen levels seen in diabetic wounds are likely in response to an altered extracellular environment (i.e. hyperglycemia, persistent inflammation, excess $\mathrm{H}_{2} \mathrm{O}_{2}$ and free radical production, and low levels of antioxidants). Collagen is the major component of extracellular tissue which provides support and strength. It is measured by monitoring the concentration of hydroxyproline, that is, synthesized by fibroblasts ${ }^{[33 \mid}$ and is vulnerable to the effects of free radicals. In the present study, after 10 days of therapy, the mean level of hydroxyproline $( \pm$ SD) was significantly higher in the LAD group as compared to that of the conventional dressing group (LAD vs. conventional $=55.2 \pm 25.1$ vs. $29.2 \pm 13.5 \mu \mathrm{g} / \mathrm{mg}$ of dry weight of tissue, $P=0.000$ ). The concentration of protein found in the wound's granulation tissue was higher in the LAD group $(12.8 \pm 6.5 \mathrm{mg} / \mathrm{g}$ wet tissue weight) than in the conventional group $(8.34 \pm 3.2 \mathrm{mg} / \mathrm{g}$ wet tissue weight), $P=0.011$.

In a study by Lobmann et al., ${ }^{[34]}$ higher concentrations of the MMP-2 and MMP-9, in conjunction with lower concentrations of TIMP-2, were found in tissue biopsies of diabetic wounds as compared to healthy controls. ${ }^{[34]}$ Another study by Liu et al. ${ }^{[35]}$ showed that high MMP-9 levels were indicative of poor wound healing in diabetics. In the present study, significant decreases in the concentrations of MMP-2 $(0.47 \pm 0.33 \mathrm{ng} / \mathrm{mg}$ tissue protein, $P=0.041)$ and MMP-9 $(0.32 \pm 0.20 \mathrm{ng} / \mathrm{mg}$ tissue protein, $P=0.037$ ) were observed in the LAD group versus the conventional group after 10 days of treatment.

Normal physiological amounts of $\mathrm{NO}$ act as a mediator for moderate vasodilatation and are required to increase blood flow and vascular permeability. Endothelial dysfunction and decreased NO production are observed in diabetic patients with a consequent delay in wound healing due to decreased tissue perfusion. ${ }^{[36]}$ After 10 days of therapy, the mean level of NO $( \pm \mathrm{SD})$ was significantly higher in the LAD group as compared to that in the conventional dressing group $(\mathrm{LAD}$ vs. conventional $=1.13 \pm 0.52$ vs. $0.66 \pm 0.43 \mathrm{nmol} / \mathrm{mg}$ protein; $P=0.019$ ).

Decreased levels of the enzymatic antioxidants, GPx, CAT, and GSH may contribute to diminished defense mechanisms against free radical overload in diabetic wounds. ${ }^{|37|}$ Antioxidants hasten the process of wound healing by destroying free radicals. ${ }^{[38 \mid}$ In the present study, after 10 days of treatment, the levels of antioxidants in granulation tissue were significantly higher in the LAD group as compared to the conventional dressing group (LAD vs. conventional $=7.0 \pm 2.4$ vs. $6.6 \pm 2.2 \mu \mathrm{mol} / \mathrm{mg}$ protein, $P=0.044$ ). Lipid peroxidation is an important pathophysiological event in diabetes. ${ }^{[39]}$ It is well known that MDA from lipid peroxidation reacts with DNA bases and induces mutagenic lesions. ${ }^{[40]}$ In the present study, after 10 days of therapy, the mean level of MDA $( \pm S D)$ was significantly less in the LAD group than in the conventional dressing group (LAD vs. conventional $=6.8 \pm 2.3$ vs. $10.4 \pm 3.4 \mathrm{nmol} / \mathrm{mg}$ protein, $P=0.024$ ).

In conclusion, LAD (intermittent NPWT and moist wound dressing) exerts a beneficial effect on diabetic wound healing as seen by a significant increase in the levels hydroxyproline, total protein, $\mathrm{NO}$, antioxidants, a decrease in MMP-2 and MMP-9, and oxidative biomarkers (MDA) as compared to conventional dressings.

The use of intermittent NPWT using LAD may be an effective alternative therapy used to achieve faster granulation of the wound bed in diabetic ulcers.

\section{Financial support and sponsorship}

Nil.

\section{Conflicts of interest}

There are no conflicts of interest.

\section{REFERENCES}

I. Singer AJ, Clark RA. Cutaneous wound healing. N Engl J Med 1999;341:738-46.

2. Eming SA, Krieg T, Davidson JM. Inflammation in wound repair: molecular and cellular mechanisms. J Invest Dermatol 2007; I 27:5 I 4-25.

3. Khodr B, Khalil Z. Modulation of inflammation by reactive oxygen species: implications for aging and tissue repair. Free Radic Biol Med 200 I;30: I-8.

4. Hallberg CK, Trocme SD, Ansari NH. Acceleration of corneal wound healing in diabetic rats by the antioxidant Trolox. Res Commun Mol Pathol Pharmacol 1996;93:3-12.

5. McDaniel DH, Ash K, Lord J, Newman J, Zukowski M. Accelerated laser resurfacing wound healing using a triad of topical antioxidants. Dermatol Surg 1998;24:66|-4.

6. Madlener M, Parks WC, Werner S. Matrix metalloproteinases and their physiological inhibitors (TIMPs) are differentially expressed during excisional skin wound repair. Exp Cell Res 1998;242:20I-I0.

7. Kakkar R, Kalra J, Mantha SV, Prasad K. Lipid peroxidation and activity of antioxidant enzymes in diabetic rats. Mol Cell Biochem 1995; 15 I: I I3-9.

8. Wiseman $\mathrm{H}$, Halliwell B. Damage to DNA by reactive oxygen and nitrogen species: role in inflammatory disease and progression to cancer. Biochem J 1996;313:17-29.

9. Sivitz WI, Yorek MA. Mitochondrial dysfunction in diabetes: from molecular mechanisms to functional significance and therapeutic opportunities. Antioxid Redox Signal 2010; 12:537-77.

10. Rolo AP, Palmeira CM. Diabetes and mitochondrial function: role of hyperglycemia and oxidative stress. Toxicol Appl Pharmacol 2006;2। 2:167-78.

II. Guo S, Dipietro LA. Factors affecting wound healing. J Dent Res 2010;89:219-29.

12. Hsu WT, Tsai LY, Lin SK, Hsiao JK, Chen BH. Effects of diabetes duration and glycemic control on free radicals in children with type I diabetes mellitus. Ann Clin Lab Sci 2006;36:174-8.

13. Flora SJ. Structural, chemical and biological aspects of antioxidants for strategies against metal and metalloid exposure. Oxid Med Cell Longev 2009;2:191-206.

14. Valko M, Leibfritz D, Moncol J, Cronin MT, Mazur M, Telser J. Free radicals and antioxidants in normal physiological functions and human disease. Int J Biochem Cell Biol 2007;39:44-84.

15. Honnegowda TM, Kumar P, Udupa P, Rao P, Bhandary S, Mahato KK, Sharan A, Mayya SS. Effect of limited access dressing on hydroxyproline and enzymatic antioxidant status in nonhealing chronic ulcers. Indian J Plast Surg 20। 4; $47: 216-20$.

16. Polack G, McCray V, Tyner T, Kane S, Vu K, Yamaguchi K Jr, Merriman J, Ishimoto M, Hasson A, Sian K, Yamaguchi KT. Accelerated wound closure in a 
diabetic mouse model after exposure to phenanthrenequinone. Ann Plast Surg 2013;70:720-5

17. Blume PA, Walters J, Payne W, Ayala J, Lantis J. Comparison of negative pressure wound therapy using vacuum-assisted closure with advanced moist wound therapy in the treatment of diabetic foot ulcers: a multicenter randomized controlled trial. Diabetes Care 2008;31:631-66.

18. Neuman RE, Logan MA. The determination of collagen and elastin in tissues. J Biol Chem 1950;86:549-56.

19. Lowry OH, Rosebrough MH, Farr L, Randell RJ. Protein measurement with the Folin phenol reagent. J Biol Chem 195I;193:265-75.

20. Young PK, Grinnell F. Metalloproteinase activation cascade after burn injury: a longitudinal analysis of the human wound environment. J Invest Dermatol 1994; 103:660-4.

21. Green LC, Wagner DA, Glogowski J, Skipper PL, Wishnok JS, Tannenbaum SR. Analysis of nitrate, nitrite, and [ $15 \mathrm{~N}]$ nitrate in biological fluids. Anal Biochem 1982; 126:131-8.

22. Beutler E, Duron O, Kefly BM. Improved method for the determination of blood glutathione. J Lab Clin Med 1963;61:882-8.

23. Ohkawa H, Ohishi N, Yagi K. Assay for lipid peroxides in animal tissues by thiobarbituric acid reaction. Anal Biochem 1979;95:35I-8.

24. Abd-El-Aleem SA, Ferguson MW, Appleton I, Kairsingh S, Jude EB, Jones K, McCollum CN, Ireland GW. Expression of nitric oxide synthase isoforms and arginase in normal human skin and chronic venous leg ulcers. J Pathol 2000; 191:434-42.

25. Rojkind M, Domínguez-Rosales JA, Nieto N, Greenwel P. Role of hydrogen peroxide and oxidative stress in healing responses. Cell Mol Life Sci 2002;59: 1872-91.

26. Moseley R, Hilton JR, Waddington RJ, Harding KG, Stephens P, Thomas DW. Comparison of oxidative stress biomarker profiles between acute and chronic wound environments. Wound Repair Regen 2004; 12:4I 9-29.

27. Joseph E, Hamori CA, Bergman S, Roaf E, Swann NF, Anastasi GW. A prospective randomized trial of vacuum-assisted closure versus standard therapy of chronic nonhealing wounds. Wounds 2000;12:60-7.

28. Kumar P. Exploiting potency of negative pressure in wound dressing using limited access dressing and suction-assisted dressing. Indian J Plast Surg
20I2;45:302-I5.

29. Kumar P, Sharma A. The limited access dressing for damage control in trauma patients. Wounds 2010;22:188-92.

30. Rasik AM, Shukla A. Antioxidant status in delayed healing type of wounds. Int J Exp Pathol 2000;81:257-63.

31. Tengrup I, Hallmans G, Agren MS. Granulation tissue formation and metabolism of zinc and copper in alloxan-diabetic rats. Scand J Plast Reconstr Surg Hand Surg 1988;22:4|-5.

32. Spanheimer RG, Umpierrez GE, Stumpf V. Decreased collagen production in diabetic rats. Diabetes 1988;37:37I-6.

33. Honnegowda TM, Kumar P, Padmanabha Udupa EG, Sharan A, Singh R, Prasad HK, Rao P. Effects of limited access dressing in chronic wounds: a biochemical and histological study. Indian J Plast Surg 20I5;48:22-8.

34. Lobmann R, Ambrosch A, Schultz G, Waldmann K, Schiweck S, Lehnert H. Expression of matrix-metalloproteinases and their inhibitors in the wounds of diabetic and non-diabetic patients. Diabetologia 2002;45: I0 I I-6.

35. Liu Y, Min D, Bolton T, Nubé V, Twigg SM, Yue DK, McLennan SV. Increased matrix metalloproteinase-9 predicts poor wound healing in diabetic foot ulcers. Diabetes Care 2009;32:1 I7-9.

36. Boykin JV Jr. Wound nitric oxide bioactivity: a promising diagnostic indicator for diabetic foot ulcer management. J Wound Ostomy Continence Nurs 2010;37:25-32.

37. Johansen JS, Harris AK, Rychly DJ, Ergul A. Oxidative stress and the use of antioxidants in diabetes: linking basic science to clinical practice. Cardiovasc Diabetol 2005;4:5.

38. Honório-França AC, Marins CM, Boldrini F, França EL. Evaluation of hypoglycemic activity and healing of extract from amongst bark of "Quina do Cerrado" (Strychnos pseudoquina ST. HILL). Acta Cir Bras 2008;23:504-I0.

39. Ceriello A, Quatraro A, Caretta F, Varano R, Giugliano D. Evidence for a possible role of oxygen free radicals in the abnormal functional arterial vasomotion in insulin dependent diabetes. Diabete Metab 1990;16:318-22.

40. Al-Bayaty F, Ameen Abdulla M. A comparison of wound healing rate following treatment with aftamed and chlorine dioxide gels in streptozotocin-induced diabetic rats. Evid Based Complement Alternat Med 2012;20 I2:468764. 